Dept. of Fish Diseases and Management,

Faculty of Veterinary Medicine, Cairo University.

\title{
MONITORING OF SEASONAL PARASITIC AND MYCOTIC PROBLEMS AFFECTING CULTURED OREOCHROMIS NILOTICUS UNDER SEMI- INTENSIVE SYSTEM
}

(With 3 Tables and 18 Figures)

By

\section{M.S. MARZOUK; M.A. ABDELAZIZ; M. MOUSTAFA and SOFIA ABOTORKIA* \\ *Alfateh University, Libya. \\ (Received at 25/2/2010)}

رصد المشاكل الطفيلية والفطرية فى مزارع البلطى النيلى شبه المكثف

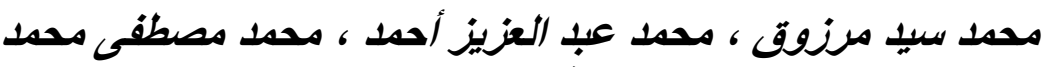
صوفيا الههادى الزيز

أجريت هذه الدراسة علي عدد 1000 سمكة من نوع البلطي النيلي في جمهورية مصر العربيه

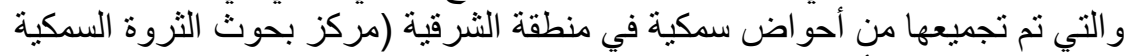

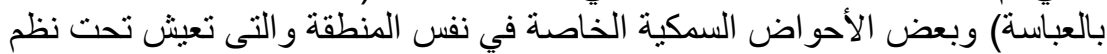

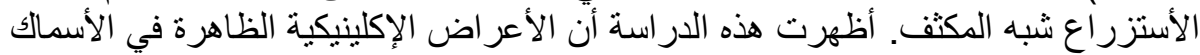

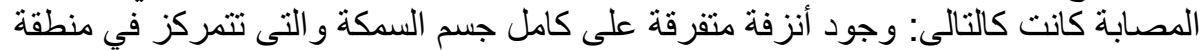

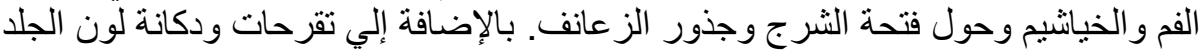

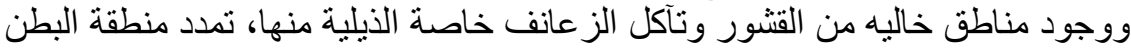

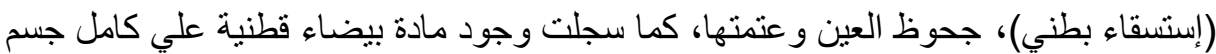

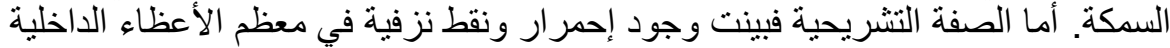

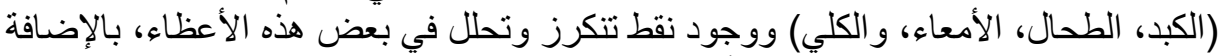

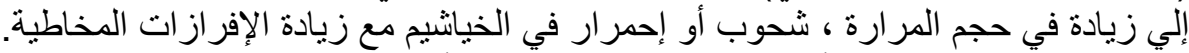

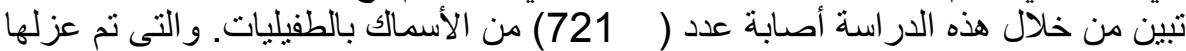

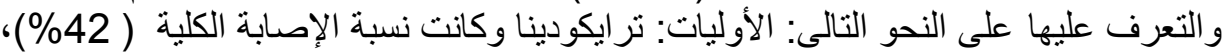

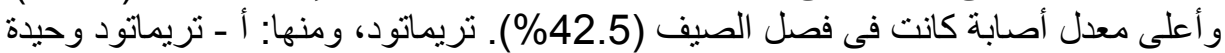

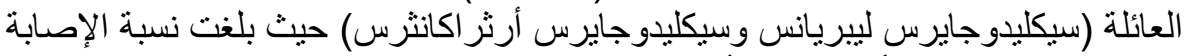

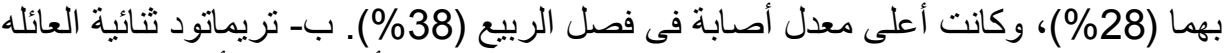

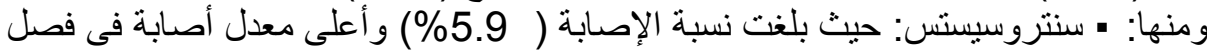

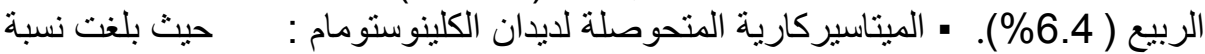
• الميتاسيركارية

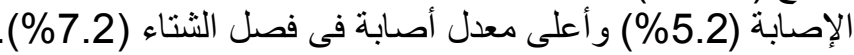

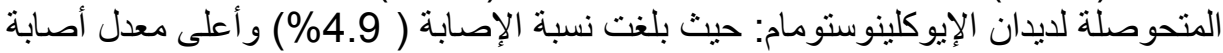

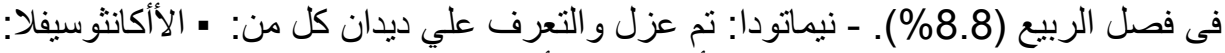

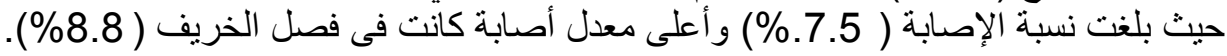




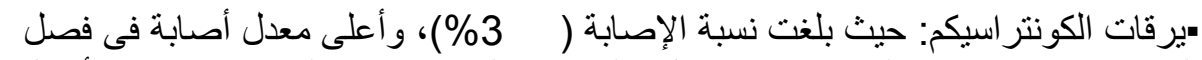

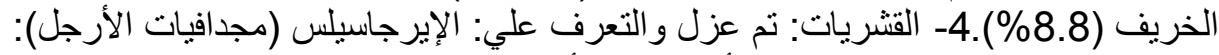

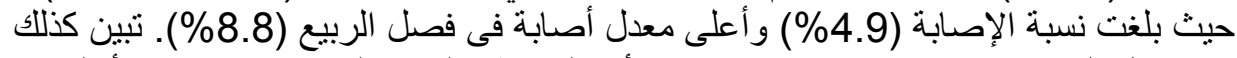

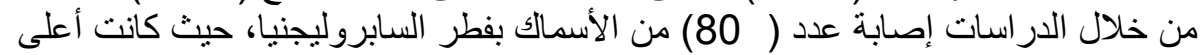

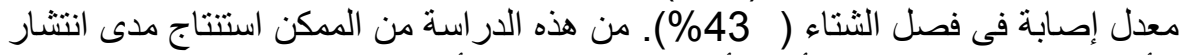

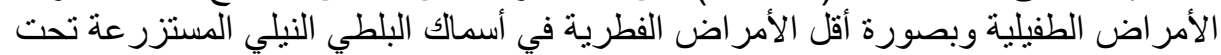

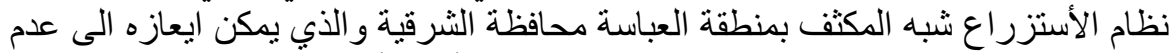

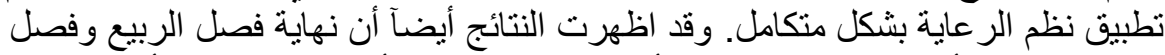

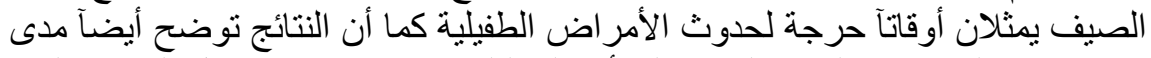

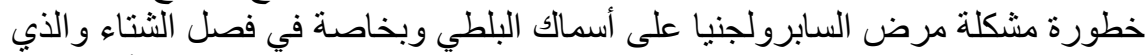

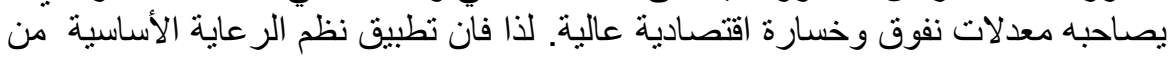

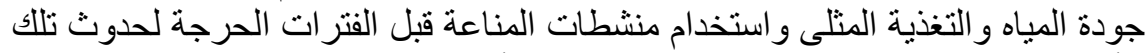
الأمر اض سوف يحد من التاثير ات السلبية لتلك الأمر اض.

\section{SUMMARY}

The study was carried out on 1000 Tilapia (O. niloticus) collected from private and governmental semi intensive earth pond (Central Laboratory for Aquatic Research laboratory (Abbassa) in Sharkia Province, through the seasons of the year 2008. The clinical signs and post mortem lesions of diseased fish were recorded. Results of the study revealed that (721) and (80) fish were found to be infected with different types of parasites and fungal infection respectively. The isolation and identification of parasites in infected fish including the following, 1-Protozoa: (Trichodina sp. in a percentage (42\%), of total parasitic disease in fish examined. The research showed that Trichodina sp. represented the highest rate of infection was observed in summer season (64.8\%). 2-Trematodes: a-Monogenia (Cichlidogyrus liberianus and Cichlidogyrus arthracanthus (28\%), the highest rate of infection was observed in spring season (38\%). b-Digenean encysted metacercaria (Centrocestes (5.9\%), Clinostomum (5.2\%), Euclinostomum (4.9\%)), and the highest rate of infection were observed in spring $(6.4 \%)$, winter $(7.2 \%)$ and spring $(8.8 \%)$ respectively 3 -Nematodes: a-Acanthocephala $(7.5 \%)$ and the highest rate of infection was observed in autumn season $(8.8 \%)$. b- Contracaecum (3\%) and the highest rate of infection was observed in autumn season (4.8\%). 4-Crustacea (Ergasilus (4.9\%) and the highest rate of infection was observed in spring season $(8.8 \%)$. The isolation and identification of mycotic diseases in infected fish revealed that the Seasonal prevalence of saprolegniosis showed that the highest rate of infection was observed in winter season (43.7\%). From this study it could be concluded the wide spread of parasitic diseases and to lesser 
extent the mycotic one in cultured $O$. niloticus under semi intensive system in Sharkia province which may be due to the improper management practice in such farms. The results revealed that late spring and summer are critical times for the occurrence of parasitic diseases, At the same time the rigorousness of saprolegnisis on $O$. niloticus specially in winter season which is associated with severe mortalities and high economic losses must be considered. So the application of the ideal system of management including good quality water, proper nutrition and using of immunstimulant will decrease the negative impacts of such diseases in their critical times of occurrence.

Key words: Parasitic, mycotic, Oreochromis niloticus.

\section{INTRODUCTION}

Tilapia are sometimes referred as aquatic chicken due to their high growth rate, adaptability to a wide range of environmental conditions, ability to grow and reproduce in captivity as well as feed on low tropic level. As a result, these fishes have become excellent candidates for aquaculture, especially in tropical and subtropical regions and the number of farms has been increasing annually all over the world (Newai et al., 2008).

Fish diseases are substantial sources of monetary losses to aqua culturists. Production costs are increased by fish disease outbreaks because of the investment lost in dead fish, cost of treatment, and decreased growth during convalescence. In nature awareness to fish disease problems are less than in captivity because diseased fishes are quickly removed from the population by predators. So causatives agents of diseases are of minimal significance under natural conditions, but can cause substantial problems when fishes are crowded and stressed under culture conditions Ruth (1990), De Buron and Roumillat (2010).

Plumb (1999) mentioned that infectious diseases are among the most serious constraints to warm water aquaculture. Woo (2006), Cedric and Neil (2007) mentioned that Parasites are causative agents of diseases with great importance in farmed fish by causing little apparent damage in fish populations, leading to pathological changes, decrease of fitness or reduction of the market value of fish, so parasites may have considerable impact on growth and behavior of fish, their resistance to other stress factors, susceptibility to predation and reduction of marketability that is why Freshwater parasites are very great ecological 
importance, as suggested by their great diversity, and by their often high prevalence and intensities of infection.

The parasitic diseases of fish in warm water of subtropical and tropical countries have a superior position and have received a significant attention in Egypt (Eissa et al., 2000). The parasitic diseases of cultured fishes may be the main cause of low body weight gain, decrease reproductive ability and high mortality; for example, parasitism has been shown to result in increased permanent stress responses believed to be linked to decreased disease resistance which results in increased overall performances and fish mortality from mixed infection (Bowers et al., 2000; Tully and Nolan 2002).

In warm water fish the Mycotic diseases constitute one of the most important diseases causing troubles in freshwater cultured fishes with several economical losses especially Saprolegniosis, some are apparently primary pathogens, many are thought to be secondary requiring predisposing factors (Udomkusonsri, 2003, Lau et al., 2009). Saprolegniosis is a serious winter disease that affects all species and ages of freshwater fishes (Stueland et al., 2005). Saprolegniosis usually increases in tilapia as water temperatures drop to a near lethal level (Aly and El-Ashram, 2000). From the aforementioned data it appears that fish diseases constitute a drastic obstacle for fish production, either due to a single infection or multiple mixed infections. Therefore, the aim of the present investigation was to through the light on the following:

1- Isolation and identification the most important parasitic and fungal agents which are commonly associated with heavy mortality among semi intensive cultured $O$. niloticus.

2- Recording the seasonal prevalence and critical times of occurrence of these diseases among the examined fish.

3- Describing the clinical picture and Postmortem lesions which associated with these infections in naturally and experimentally infected fish.

\section{MATERIALS and METHODS}

\section{Material}

Naturally infected fish: A total number of one thousand apparently infected Nile-tilapia ( $O$. niloticus) in a body weight range $(25-150 \mathrm{gm})$ were collected during the period from January-2008 to December-2008 during the occurrence of various mortalities in private and governmental semi-intensive earthen pond in Sharkia governorate. Fish were transferred alive or freshly dead as soon as possible to the Central 
Laboratory for Aquatic Research laboratory (Abbassa). The live fish were placed in strong plastic bags with compressed air then packed in a large ice box surrounded with crushed ice. The recently dead fish specimen were kept on ice bags to be subjected to full clinical, postmortem, parasitological and mycological examinations.

Chemicals:- Normal physiological saline solution $(0.9 \% \mathrm{NaCl})$ Formalin 5\% - Ascending grades of ethyl alcohol (30, 50, 70, 90\% and absolute) - Clove oil - Xylene - Canada balsam - Glycerin-gelatin (1:1) Glycerin-Alcohol (1:4) - Lactophenol (Lactic acid and phenol)- Polyvol. Parasite stain-Acetic acid alum carmine according to Kabata (1985)Gimsa stain.

Media used for Mycotic isolates: Sabauraud's Dextrose agar (SDA)

Fungal stain Lacto phenol cotton blue stain.

\section{Methods}

The fish were examined directly for clinical abnormalities and post-mortem changes according to Amlacher (1970).

I- Incidence of parasitic and fungal infections in diseased O.niloticus:

II- Seasonal prevalence of Parasites and fungus isolated from naturally infected $O$.niloticus.

\section{III- Parasitological examination and identification.}

\section{1- Protozoal examination:}

Was carried out according to Lucky (1977).

\section{2- Examination of monogenetic trematodes and encysted metacercaria:}

a- Skin examination: This was carried out by scraping the external body surface of the examined fish, the trunk, head, eyes, nostrils, mouth and fins (dorsal, pelvic, pectoral and caudal fin) especially the part having ulcers, petecheal hemorrhage, sloughed scales or slimness. The scraped material was accumulated in small petridish with a small amount of formal saline and left in refrigerator overnight for relaxation of monogenia and separated from the mucus or any debris to become ready for mounting and staining.

b- Gill examination: Was carried out according to Lucky (1977). Kabata, (1985).

\section{3- Examination of Nematodes:}

Smears were taken from intestinal wall, squash preparations from liver, spleen, kidney and intestinal scrapings on cover slides fixed in formalin $10 \%$ for detection of eggs, larva and adults of nematode sp. scraping of intestinal wall and was carried out according to Kabata, (1985). 


\section{4- Examination of Crustacae:}

Crustaceans were collected from fish gills, preserved in glycerin alcohol and fixed by glycerin gelatin the examination was carried out according to Kabata, (1985).

\section{IV-Mycological isolation and identification:}

Samples from infected tissues (skin, fins, gills and eyes) were obtained by sterilized forceps and inoculated into Sabauraud's Dextrose agar. Identification of pure culture was carried out according to Willough (1978).

\section{RESULTS}

I- Prevalence of parasitic and fungal infections in examined O.niloticus: The examination of naturally infected $O$. niloticus collected from the fish ponds at Abbassa fish farm revealed that the prevalence were $72.1 \& 8 \%$ of parasitic and mycotic affections, respectively Table (1).

Table 1: The incidence of different parasitic and fungal infection in naturally infected $O$. niloticus.

\begin{tabular}{|c|c|c|c|}
\hline Isolated organism & $\begin{array}{c}\text { Total No. of } \\
\text { examined } \\
\text { Fish }\end{array}$ & $\begin{array}{c}\text { No. of } \\
\text { naturally } \\
\text { infected } \\
\text { Fish }\end{array}$ & $\begin{array}{c}\text { Percentage of } \\
\text { isolation }\end{array}$ \\
\cline { 1 - 1 }$\bullet$ Parasites & \multirow{2}{*}{1000} & 721 & $72.10 \%$ \\
\cline { 1 - 1 } \cline { 3 - 4 } - Fungi & 80 & $8.00 \%$ \\
\hline
\end{tabular}

II- Seasonal prevalence of Parasites and fungus isolated from naturally infected $O$.niloticus.

Table 2: Seasonal prevalence of parasites and fungus isolated from naturally infected O.niloticus.

\begin{tabular}{|c|c|c|c|c|c|c|c|c|c|c|c|}
\hline \multirow{3}{*}{ Season } & \multirow{3}{*}{$\begin{array}{c}\text { No of } \\
\text { exa. } \\
\text { Fish }\end{array}$} & \multicolumn{8}{|c|}{ Parasites } & \multirow{2}{*}{\multicolumn{2}{|c|}{$\frac{\text { Mycotic }}{\text { Saprolegnia }}$}} \\
\hline & & \multicolumn{2}{|c|}{ Protozoa } & \multicolumn{2}{|c|}{ Trematodes } & \multicolumn{2}{|c|}{ Nematodes. } & \multicolumn{2}{|c|}{ Crustacea } & & \\
\hline & & No & $\%$ & No & $\%$ & No & $\%$ & No & $\%$ & No & $\%$ \\
\hline Spring & 250 & 120 & 48 & 148 & 59.2 & 23 & 9.2 & 22 & 8.8 & 12 & 15.0 \\
\hline Summer & 250 & 162 & 64.8 & 115 & 46 & 26 & 10.4 & 9 & 3.6 & 0 & 0 \\
\hline Autumn & 250 & 81 & 32.4 & 97 & 38.8 & 34 & 13.6 & 5 & 2.0 & 33 & 41.2 \\
\hline Winter & 250 & 62 & 24.8 & 80 & 32 & 22 & 8.8 & 13 & 5.2 & 35 & 43.7 \\
\hline
\end{tabular}


Table 3: Seasonal prevalence of parasitic species isolated from naturally infected $O$. niloticus

\begin{tabular}{|c|c|c|c|c|c|c|c|c|c|c|c|c|c|c|c|}
\hline \multirow{3}{*}{ Season } & \multirow{3}{*}{$\begin{array}{c}\text { No. of } \\
\text { examined }\end{array}$} & \multicolumn{2}{|c|}{ Protozoa } & \multicolumn{8}{|c|}{ Trematodes } & \multicolumn{4}{|c|}{ Nematodes } \\
\hline & & \multicolumn{2}{|c|}{ Trichodina } & \multicolumn{2}{|c|}{$\begin{array}{c}\text { Cichlidogyrus } \\
\text { sp. }\end{array}$} & \multicolumn{2}{|c|}{$\begin{array}{l}\text { Clinostomum } \\
\text { sp. (EMC) }\end{array}$} & \multicolumn{2}{|c|}{$\begin{array}{l}\text { Euclinostomum } \\
\text { sp. (EMC) }\end{array}$} & \multicolumn{2}{|c|}{$\begin{array}{l}\text { Centrocestus } \\
\text { sp. (EMC) }\end{array}$} & \multicolumn{2}{|c|}{$\begin{array}{c}\text { Acanthocephala } \\
\text { sp. }\end{array}$} & \multicolumn{2}{|c|}{$\begin{array}{c}\text { Contracaecum } \\
\text { sp. }\end{array}$} \\
\hline & & No & $\%$ & No & $\%$ & No & $\%$ & Fish & $\%$ & No & $\%$ & No & $\%$ & No & $\%$ \\
\hline Spring & 250 & 120 & 48.0 & 95 & 38.0 & 15 & 6.0 & 22 & 8.8 & 16 & 6.4 & 20 & 8.0 & 3 & 1.2 \\
\hline Summer & 250 & 162 & 64.8 & 84 & 33.6 & 7 & 2.8 & 9 & 3.6 & 15 & 6.0 & 18 & 7.2 & 8 & 3.2 \\
\hline Autumn & 250 & 81 & 32.4 & 68 & 27.2 & 12 & 4.8 & 5 & 2.0 & 12 & 4.8 & 22 & 8.8 & 12 & 4.8 \\
\hline Winter & 250 & 62 & 24.8 & 33 & 13.2 & 18 & 7.2 & 13 & 5.2 & 16 & 6.4 & 15 & 6.0 & 7 & 2.8 \\
\hline Total & 1000 & 425 & 42.5 & 280 & 28.0 & 52 & 5.2 & 49 & 4.9 & 59 & 5.9 & 75 & 7.5 & 30 & 3.0 \\
\hline
\end{tabular}




\section{IV- Identification of isolated parasites}

\section{1- Protozoa:}

Trichodina: Trichodina species were observed in gills and skin scrape (Fig.1.a.b).
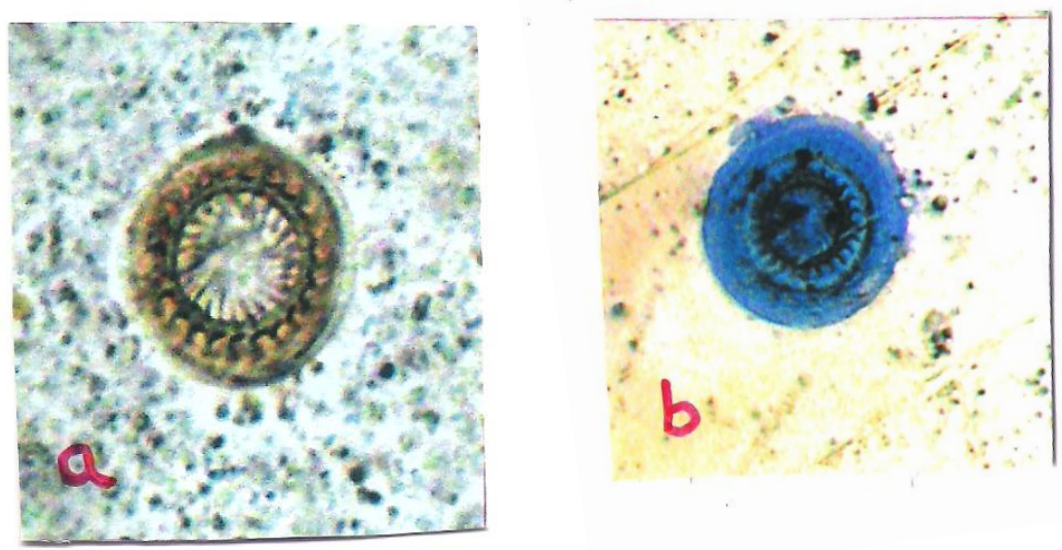

Fig. 1: Trichodina ciliated protozoa in wet mount (a) and stained with Geimsa stain (b) isolated from O. niloticus.

\section{2- Trematodes:}

2- a-Monogenia: the Microscopical examination revealed the presence of Cichlidogyrus liberianus (Fig.2). and Cichlidogyrus arthracanthus (Fig.3).

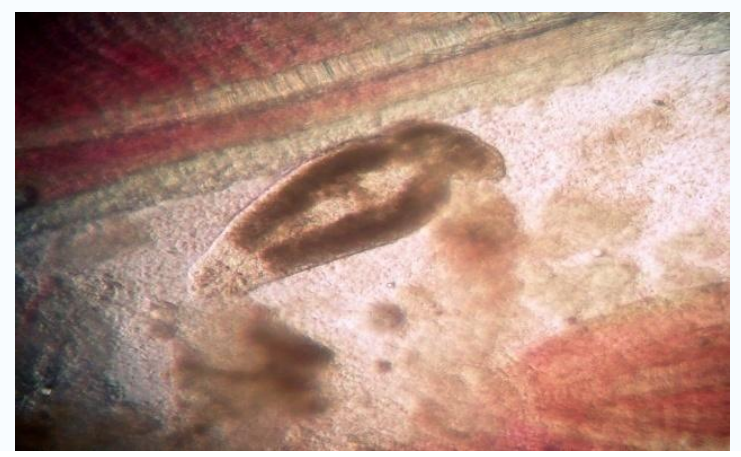

Fig. 2: Cichlidogyrus Liberianus showing attached to gill filaments on O.niloticus. 


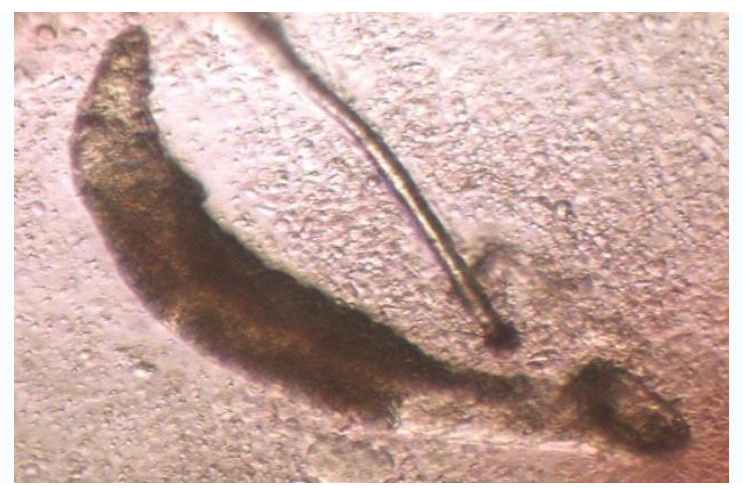

Fig. 3: Cichlidogyrus arthracanthus showing attached to gill filaments on O.niloticus.

\section{2- d- Digenea}

The results revealed the presence of Centrocestus sp., Clinostomum and Euclinostomum Encysted metacercaria sp(Fig 4-5-6) The external examination of some infected $O$. niloticus revealed the presence of scattered visible yellow to orange pea like encysted metacercariae on skin and embedded in the musculature with irritated scales Metacercariae of Clinostomum tilpaiae In spite of the large size (3-7 mm) of the clinostomatid cysts, The encysted metacercariae were detected in both skin and internal organs (branchial cavity, pharynageal regions and gills). Metacercariae of Euclinostomum Encysted metacercariae were large pea sized. They were spherical in shape, dark yellowish in color and embedded in the tissues of either anterior or posterior portions of the kidneys.

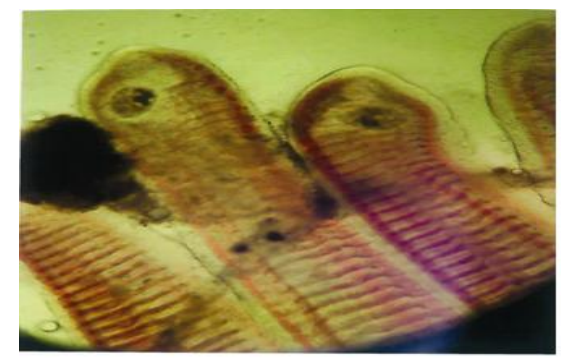

Fig. 4: Encysted Centrocestus metacercariae in the gills of infected O. niloticus. 


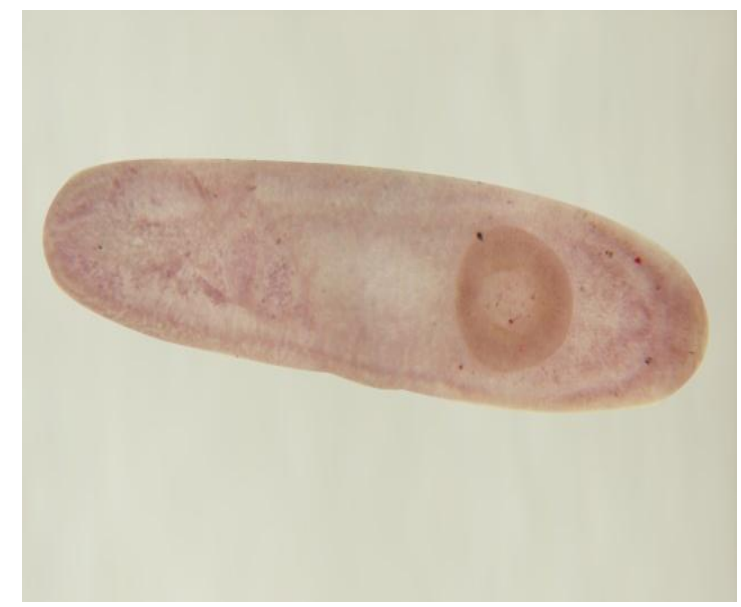

Fig. 5: Stained excysted Clinostomum sp larvae.

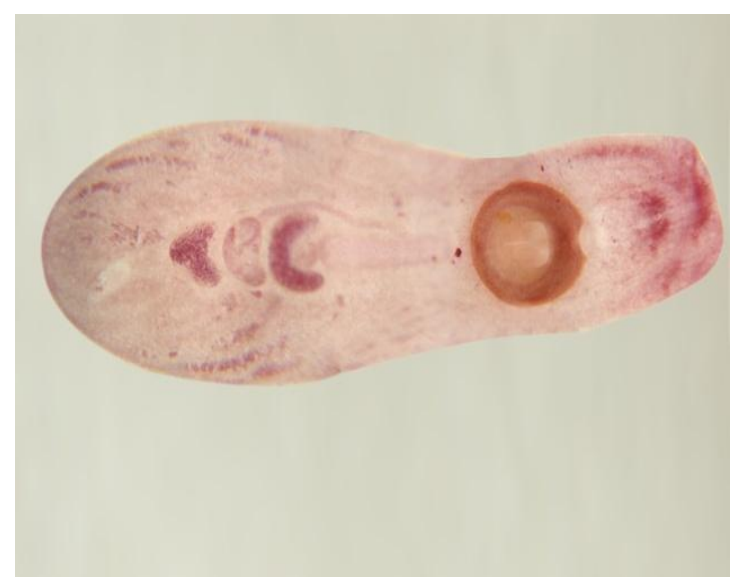

Fig. 6: Stained excysted Euclinostomum sp. larvae.

\section{3- Nematodes:}

3- a- Acanthocephala: The parasitological examination revealed the presence of acanthocephalan tilapiae. (Fig.7-10).

3-b-Contracecum: The parasitological examination revealed the presence of acanthocephalan tilapiae. (Fig.11-13). 


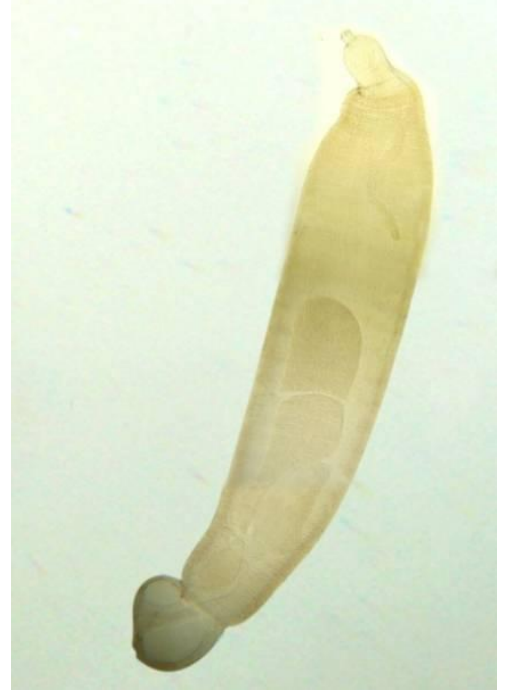

Fig. 7: Male Acanthocephala tilapae in O.niloticus

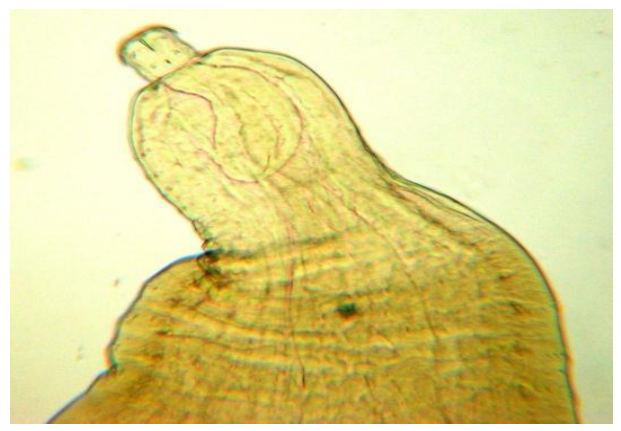

Fig. 8: Anterior end of Acanthocephala tilapae.

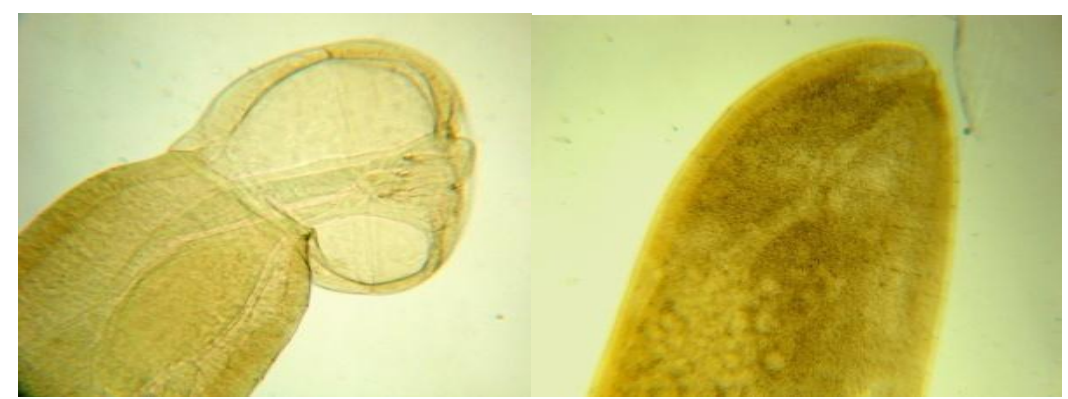

Fig. 9: Posterior end of male Acanthocephala tilapae
Fig. 10: Posterior end of female Acanthocephala tilapae 


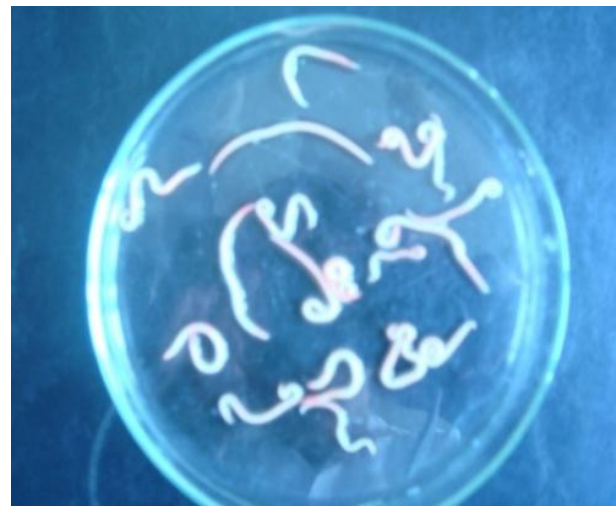

Fig. 11: Contracaecum sp. Larvae

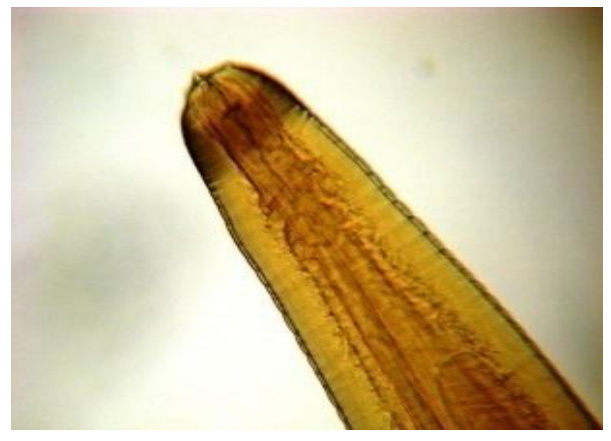

Fig. 12: Anterior end of Contracaecum sp. larvae

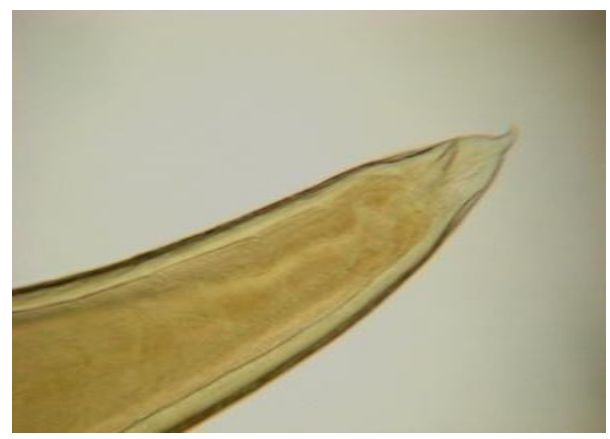

Fig. 13: Posterior end of Contracaecum sp. larvae

4- Crustacia: Isolation of Ergasilus from $O$. niloticus was obtained from gills (Fig.14-15). 


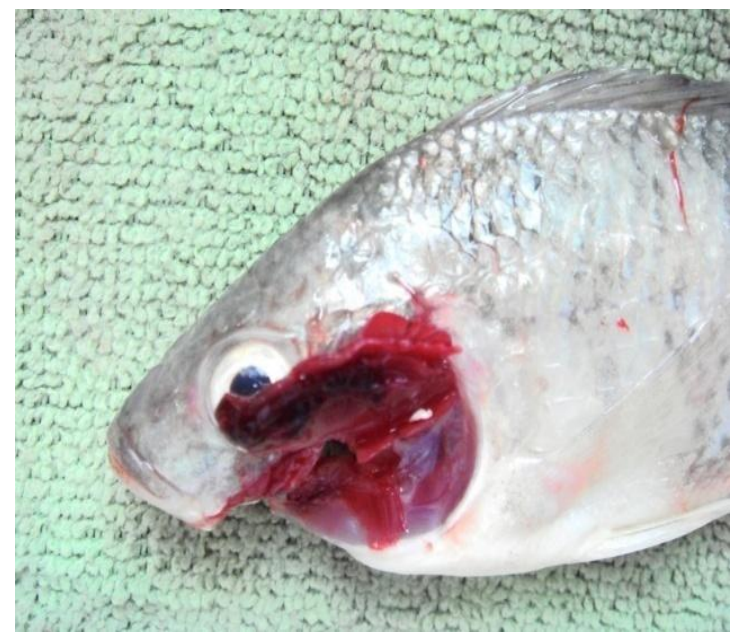

Fig. 14: Ergasilus sp. attached to the gills of O.niloticus.

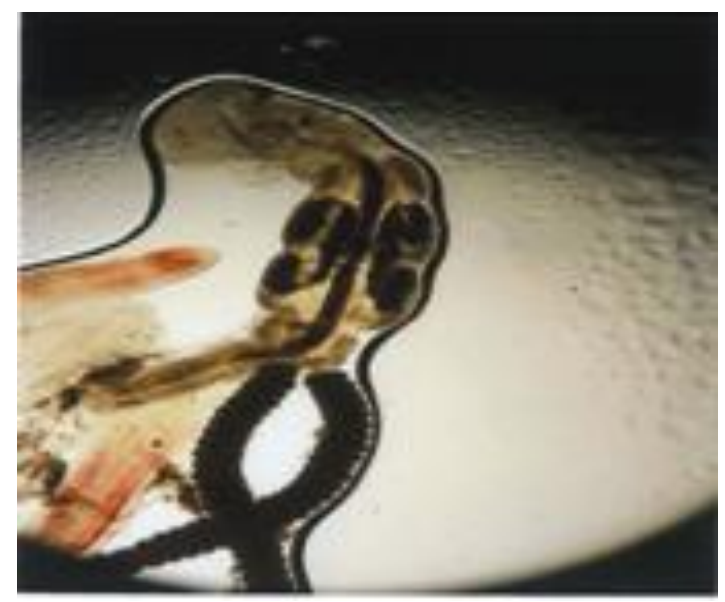

Fig. 15: Ergasilus sp. in wet mount

\section{VI- Identification of isolates of fungal organisms}

The results of mycological examination allowed the isolation of 80 isolates from infected $O$. niloticus sampled from skin, gills, eye, and mouth lesions of infected O.niloticus (Fig.16-17) showed masses of mature and immature sporangia filled with large number of sporangiospores, the hyphae appeared profusely branched and were non septated, these morphological findings were characteristic of the saprolegnia species. The characteristic appearance of Saprolegnia sp. on Sabauraud's Dextrose agar (Fig. 18). 


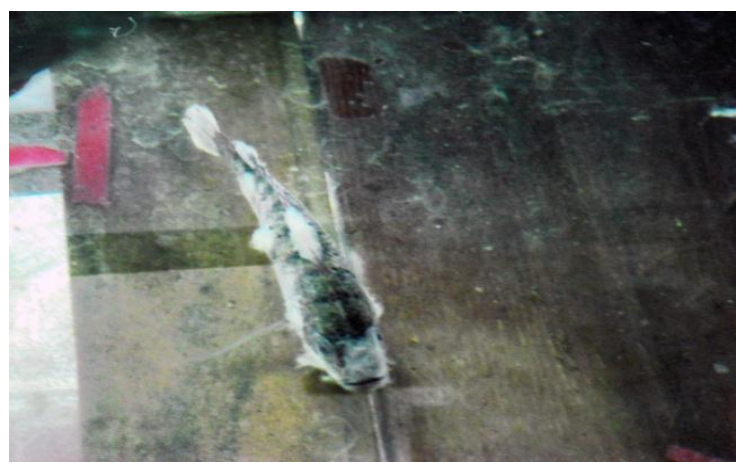

Fig. 16: Naturally infected O.niloticus showing cotton-like material on the skin.

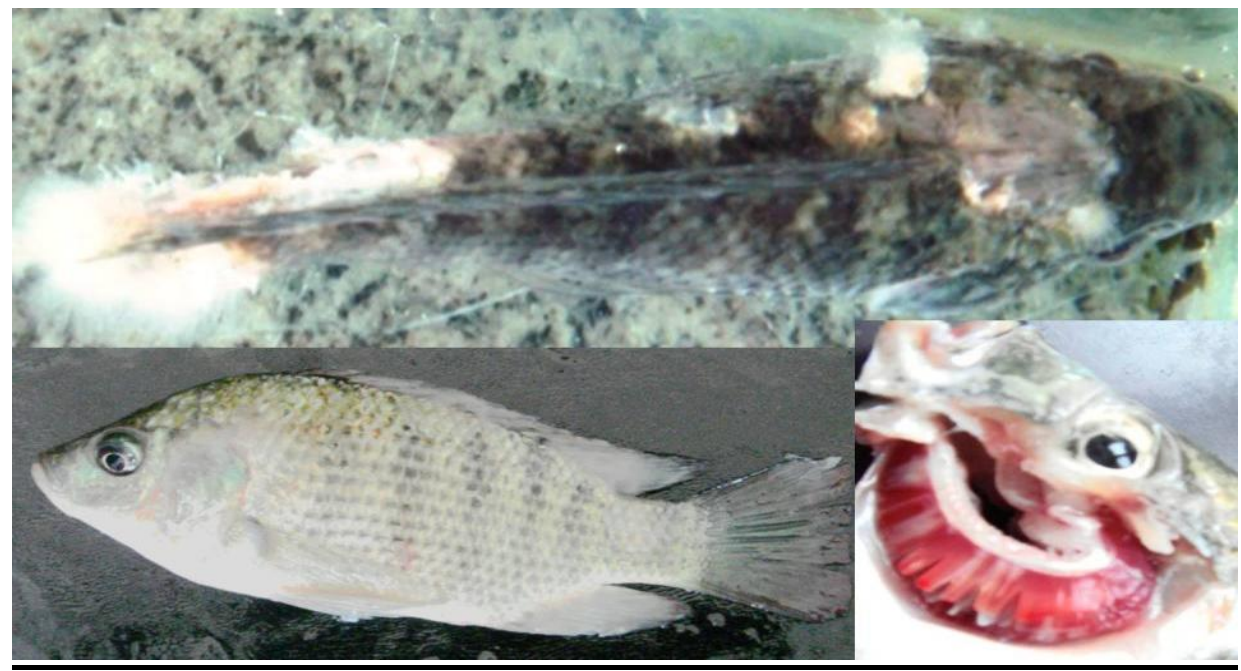

Fig. 17: Saprolegnia sp. showing cotton-like material on the skin surface, eye, fins, gills and mouth

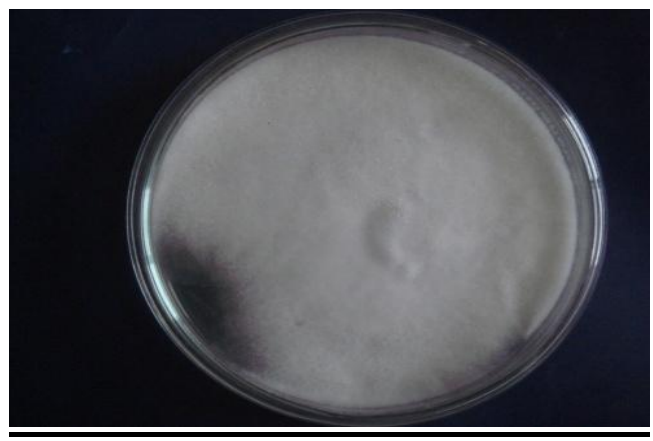

Fig. 18: Saprolegnia sp. on Sabauraud's Dextrose agar 


\section{DISCUSSION}

The present investigation was planned to detect the seasonal critical times for the occurrence of important parasitic and mycotic diseases that affecting $O$. niloticus under semi-intensive culture system in Sharkia Province. The detection of those critical times will help for lowering the negative impacts of such diseases.

The results showed that parasitic infestations were found to be the major problems and the most prevalent diseases infecting cultured tilapia in semi-intensive farms. The percentages of parasitic and fungal fish pathogens represent $72.5 \%$ and $8 \%$ of examined diseased fish respectively. Some of these are obligate pathogens while others are opportunistic facultative organisms producing disease when fish health is compromised by injury or environmental stressors (Plumb, 1999). The results agree with El-Nobi (1998) and this could be attributed to the pond management, including poor water quality, improper nutrition and other stressors affecting $O$. niloticus.

Regarding the isolated parasites, Protozoa are the most prevalent Parasitic diseases of $O$. niloticus, Ruth (1990). Tricodinids are the most commonly encountered symbiotic groups in the aquatic environment. They found mainly on the skin and gills, either as parasites or as commensals and show very little host specificity (Woo, 2006). The results of parasitological examination and identification revealed the presence of Trichodina sp. in a percentage (42.5\%) of total parasitic disease in fish examined. The research showed that Trichodina sp. represented the highest rate of infection among detected parasites in O. niloticus, the results agree with (El- Gawady et al., 1992) and Younis (1999).

Dealing with the seasonal dynamics of Trichodina sp. parasite in the examined fish, it was clear that the higher prevalence was observed in summer season (64.8\%), followed by spring (48\%), then autumn $(32.4 \%)$ and the least percentage was recorded in winter $(24.8 \%)$. These results were similar with that obtained by Brewster (1997); El-Nobi (1998); Morozinska (2002) and Attia (2004). The higher prevalence of Tichodina infection among Tilapia during summer and spring seasons could be attributed to the high organic matter and the high temperature which are more suitable for parasite reproduction, while in winter the water temperature decreased and the parasitic prevalence consequently decreased (Attia 2004; Awad, 2007). On the other hand, Ramadan (1991); Mesally (1994); Salah et al. (1995) and Woo (2006) mentioned that winter and spring was found to be the season for sever Trichodina 
infection in fishes which stressed by harsh winter conditions and the lowest percentage of infection was recorded in summer. The results also revealed that the main clinical signs observed in heavily infected $O$. niloticus may exhibited a grayish-blue color, formed by excessive mucus secretion in skin, gills and peeled epithelia, sluggish swimming. The excessive epithelial growth is believed to be a protective reaction, from the fish against the parasite. The results of Trichodina infection in the examined fish proved the drastic damage on the skin and gill epithelium. Similar signs were coincided with the description given by Noga (1996); Paperna (1996); Attia (2004); Awad (2007) and Abd ElGhany et al. (2009).

The results of parasitological examination and identification revealed the presence of gill monogeneans at percentage (28\%) of total parasitic disease in examined $O$. niloticus. This result was almost in agreement with El-Gawady et al. (1992) and Dewra (1995). A higher percentage was recorded by El-Gohary (2000) which was (80\%), $(78.9 \%)$ respectively. The variation in prevalence may be attributed to season, locality, physiological status of examined fish and environmental factors. The results revealed that the seasonal prevalence of monogenetic trematodes was highest in spring season (38\%), followed by summer (33.6\%), Autumn (27.2\%) and then in Winter (13.2\%). These results were similar with that recorded by El-Nobi (1998); El-Gohary (2000); Attia (2004) and Awad (2007) this result may be due to that during warm seasons the climate temperature is suitable for the life cycle of the parasites.

The clinical signs observed in heavily infected $O$. niloticus with ectoparasitic monogenea usually results in excessive mucus, loss of appetite, sluggish movements and the fish swam near the surface of water. The infested fishes showed increased breathing frequency, and the gill covers were stretched open widely. The gills were pale in some fishes, hyperemic in others and covered with mucus secretions forming cloudy film of slime. Infested fishes were anemic and the fins were ragged with partial detachment of scales. Microscopically, the monogeneans were found attached to the gill filaments. Such obtained results are nearly similar those of these clinical signs may be attributed to the organs of attachment and mode of feeding of monogenia. The hamuli, marginal hooklets, suckers and clamps of monogeneans all have direct contact with host tissue and may afflict mechanical damage directly. These result supported those of Attia (2004); Woo (2006); Awad (2007) and Abd El-Ghany et al. (2009). 
The results noticed in this work proved that mixed infection of Trichodina and monogeneans were more prevalent. However, monogenea can serve as vectors for viral and bacterial pathogens of fish which provided a portal of entry for invasive bacteria due to damage of the fish epithelium. Also, because they propagate and transferred rapidly between fishes under farming conditions this may be leading much damage to high morbidity and mortality. These were proved previously by Cusack and Cone (1986).

The results of parasitological examination and identification revealed the presence of three types of digenean encysted metacercariae in examined $O$. niloticus. Centrocestus sp. represented the highest one at percentage $(5.9 \%)$ of total parasitic disease in examined fish. The results proved seasonal fluctuations among the examined fish. It was especially high during the warm season of the year in fresh water due to active shedding of cercariae. Similar observation was reported by Paperna, (1996); El-Nobi, (1998); Attia, (2004) and Awad, (2007), the last author recorded that encysted metacercaria (Centrocystus formosanus) were found in gills of black carp at the prevalence of $100 \%$ along the year. This may be attributed to the high abundance of the intermediate snail host in the examined earthen ponds in which black carp were reared.

The results revealed that Centrocestus species encysted metacercariae were detected in the gills of O.niloticus without any clinical signs in low infection rate. While the main clinical signs observed in heavily infested fish were respiratory distress, decreased feed intake and increased mucus secretion. The infected area showed inflammatory reaction especially in early infestation or when the cyst, was ruptured. This condition might represent a response to prolonged irritation by the parasite and its toxic product or the hyperplasia of chondrocytes or may be due to decrease the oxygen tension in the affected area (Attia 2004; Awad 2007 and Abd El-Aal et al., 2008).

Low infection rates were recorded for Clinostomum and Euclinostomum spp. at percentage (5.2\%) and (4.9\%) respectively. Results of the previous related studies, Abd-Alkareem (2000) found the prevalence rate was $(4.4 \%)$ and $(0.5 \%)$ respectively. Yimer (2000) found (9.09\%) of Clinostomum and only 1 Euclinostomum species from all investigated fish. who found that $34 \%$ and $29 \%$ of this fish species were infected with these types of metacercariae, respectively; and that of Abd El Rahman (2005), who found that $45 \%$ and $11.8 \%$ of $O$. niloticus were infected with Clinostomum species and Euclinostomum species metacercariae, respectively. This can be refered to the difference in 
sampling periods and the ponds from which the examined fishes were obtained. The results also revealed that the seasonal prevalence of Clinostomum species and Euclinostomum species were during winter and spring seasons respectively. This may be due to the suppressed immunity of the cultured fish during cold temperature. It is worth to mention that extrapolation of seasonal variations from direct counts of larvae in fish since such infections normally persist for over 12 months, these results are in line with several authors as El-Nobi (1998); Attia (2004) and Woo (2006).

The results also revealed that the main clinical signs of Clinostomum infection observed in moderate and higher intensity of infection which showed debility, retarded growth, excessive mucus secretion, increased in the opercula movement and protrusion of operculum. Yellowish to orange color, pea like cyst were found scattered on skin and in bronchial cavity. In case of heavy infection, cysts were arranged in agape-like cluster. In dead tilapias, larvae encysted and moved over the mesentery and on skin. On the other hand, pathological impact of infection with Euclinostomum was not often obvious and depended on their number. Few cases showed related growth, abdominal distention and reddish ascetic fluid in the abdominal cavity, which could be attributed to functional damage of kidney. Euclinostomum was found distributed along the kidneys of infected tilapia in the form of grayish cyst. Congestion of infected kidneys was also observed. The present data were in agreement with previous observations (Paperna 1996; Abd El Rahman 2005; Abd El-Aal et al., 2008).

The results of parasitological examination and identification revealed the presence of Contraceacum nematode at percentage (3\%), it was higher during autumn (Abu-El-Ezz, 1988) While, Varjabedian (1993) mentioned that the majority of nematodes, reached their peak of infection during spring and summer, Aloo (2002) mentioned that no seasonal changes was recorded in infection level. This phenomenon may be attributed to many factors interacted together such as water temperature, fish host length, sex and feeding habits and propagation of the intermediate hosts and each nematode parasites had its own season of prevalence that varied in different hosts.

The results also revealed that the main Clinical signs of Clinostomum infection observed the located of Contracaecum species larvae in the abdominal cavity causing abdominal distention. Also, the effect results from mechanical damage to the internal organs and production of toxic substances. Larvae penetrate in to the intermediate 
host's body through the wall of digestive tract and lead to its death, inflammatory response of digestive tract and pressure on internal organs. Intestine was voided from food. In severe infections, low body gain is common sign. Nematodes may not even show signs of illness, but they often have reduced reproductive capacity. The present result nearly coincided with that recorded by Abu-El-Ezz (1988); Moravec (1994) and Barson (2004).

Acanthocephala tilapiae was observed in a high prevalence as parasitic infection that varied from the other parasites and another of all host species analyzed (Ayotunde 2007; Omar et al., 2008). The results of parasitological examination and identification revealed the presence of Acanthocephala tilapiae at percentage (7.5\%) that was prevalent during autumn. While Gihan (1999) recorded that the highest rate was in spring followed by autumn. (Omar et al., 2008) showed that high prevalence of Acanthocephala tilapiae was observed in all host species analyzed. They mentioned that worms appear to be recruited in the summer, develop and mature through the winter, and reproduce sexually in late winter and spring. In addition Differential exposure to parasites and host susceptibility may explain the marked variation in parasite abundance among hosts. There were no clinical signs in light infection with Acanthocephala tilapiae parasite. While, there were signs of emaciation and congested intestine in heavy infection. These findings associated with infection are in harmony with those recorded by Kabata (1985). In the final host the Pathogencity of acanthocephala is related to the mode of attachment of the parasite species and to the systematic affiliation of the host. Long necked acanthocephalans which deeply penetrate into or through the intestinal wall with their presoma are more pathogenic than species with a short neck and a shallow mode of anchorage (Kabata 1985; Woo 2006).

The results of parasitological examination and identification revealed the presence of Ergasilus sp. at percentage (4.9\%), a higher prevalence was recorded in spring. While Mostafa et al. (1991) and Molnar et al. (1997) recorded that high level of Ergasilus infestation in summer and autumn seasons. This could be related to the environmental conditions and the presence of the infective copepodids.

The results also revealed that the main clinical signs of Ergasilus infection were pale gills in mild to moderate infestation, erosion, degeneration and necrosis in gill filaments in sever cases, gills damage that resulted in loss of surface area for respiration and lead to suffocation, particularly at high water temperature and Excessive 
accumulation of mucus in the gill, This in turn may result in reduced growth rates and greater mortality (Grabda 1991; Mostafa et al., 1991; Molnar et al., 1997; Abd El-Rahim 1998; Woo 2006).

The results of mycological examination and identification revealed the presence of mycotic infection at percentage $8 \%$ of total diseased examined fish. This may be due to the fact that most of the serious mycotic pathogens are mostly secondary in nature and need great stress on such cultured fishes in order to find the porta of entery for producing a disease. The stress factors usually include environmental fluctuations and improper management practices with poor water quality (Udomkusonsri, 2003). The wet mounts from skin and gill tissues of infected O.niloticus showed the presence of large non-septet tubular cells. Spores of the fungi attach to injured or unhealthy tissue and establish a colony (mycelium). Microscopically, the identified agent was Saprolegnia diclina which found among $O$. niloticus in the examined semi-intensive farms in the winter season specifically. This disease (Saprolegniosis) is a serious disease that affects all species and ages of freshwater fishes and can also affect many estuarine fish (Woo and Bruno 1999; Aly and El-Ashram 2000; Polacheck 2007; Woo 2007). The low temperature constitutes a great stress factor affecting the health condition of O.niloticus and renders them prey to Saprolegnia fungus. (Mesallhy 1994; Naguib 1994; Aly et al., 1996; Aly and El-Ashram 2000; Polacheck 2007; Osama et al., 2008; Zaki et al., 2008).

The results revealed that the signs of Saprolegnia infection including general external signs which appeared anywhere on the body surface, fins, eyes and gills. The infected fish often develop grayishwhite cotton-like growths on skin, fins, gills and eyes. The diseased fish showed hyperactivity and obvious evidence of irritation such as rubbing against the sides or bottom of tank which may be attributed to the inflammatory reactions, erythema at the base of fins, ulceration of the skin, this may be due to toxin secreted by saprolegnia hyphae, oomycete or zoospores due to fungal cells (hyphae) invade the injured tissue from which they infect surrounding healthy tissue. Also, loss of equilibrium with nervous signs, blindness, and enlargement of abdominal were also recorded. Evidence of respiratory distress was recorded. The gills appeared pale in colour with profuse mucus and covered by tufts of fungi. The same findings were also recorded by (Ruth 1990; Aly and ElAshram 2000; Udomkusonsri. 2003; Osama et al., 2008; Zaki et al., 2008). The observed pale color of gills could be due to the coating of the 
gills by profuse mucus, necrotic debris and secondary mycosis (Plump 1997).

In conclusion, the result of this work proved the wide spread of parasitic and to lesser extent fungal infections in the $O$. niloticus cultured under the semi-intensive system in the earthen ponds. The wide spread of such pathogens are due to the improper management practice. The results revealed that summer and late spring are critical times for the occurrence of parasitic diseases. At the same time the problem of saprolegniosis in winter season represents an important problem for $O$. niloticus semi intensively cultured in earthen ponds, especially after the days of severe cold weather fronts. A sever economical impact could be waited from the heavy fish mortality and high fish loss, so proper managemntal practices should be applied during these critical times that render $O$. niloticus susceptible for the occurrence of such diseases. Raising of water column, continuous flow of water in the days of sever cold weather as well as incorporation of immune-stimulant in fish ration could aid in avoiding of such loss by raising the fish resistance against these parasites and fungal agents.

\section{REFERENCES}

Abd-Alkareem, O.M.A. (2000): Clinical investigation of digenean metacercarial infestation in tilapia in the High Dam Lake, Egypt. Thesis, M.V.Sc., Vet. Med., Assiut Univ., Egypt.

Abd-Al-Aal, Z.; Amer, O.H.; Badawy, A.I.I. and El-Ashram, A.M.M. (2008): Digenetic trematodes of the Little Egret, Egretta garzetta, and possibility of transmission to Oreochromis niloticus at El-Abbassa fish farms, Egypt. $8^{\text {th }}$ International Symposium on Tilapia in Aquaculture, Cairo, Egypt (12-14 October 2008) Vol. II: 1351-1364.

Abd El-Ghany, N.; El-Khatib, N. and El-Ashram, A.M.M. (2009): Some studies on ulcerative fish syndrome in cultured Oreochromis niloticus in. $1^{\text {st }}$ Biotechnology conference held at National Research Center, Cairo, Egypt.

Abd El-Rahim, G.E.A. (1998): "Studies on the main parasitic diseases affecting cultured fish and its influences by some ecological factors" Ph. D. Thesis, Fac. Vet. Med. Zagazig. University. Egypt.

Abd El Rahman, A.M.M. (2005): Studies on prevailing parasitic diseases among some fresh water fishes caused by digenetic trematodes. SCVMJ, 8 (1): 13-24. 
Abu El-Ezz, N.M.T. (1988): Amorphologycal study in some intestinal parasites of freshwater fishes n Egypt. M.V.Sc. Thesis, Faculty of Veterinary Medicine, Cairo University.

Aloo, P.A. (2002): A comparative study of helminth parasites from the fish Tilapia zillii and Oreochromis leucostictus in Lake Naivasha and Oloidien Bay, Kenya., Journal of Helminthology, 76:95-102.

Aly, S.; Mayberry, L. and Meleigy, A. (1996): "Phathological studies on sprolegniosis among Oreochromis niloticus." Zag. Vet. J., 24 (3): 51-56.

Aly, S.E.M. and El-Ashram, A.M.M. (2000): Some factors contributing to the development of saprolegniosis in nile tilapia (O.niloticus). Alex. J. Vet. Scince. 16, (1): 165-174.

Amlacker, E. (1970): "Text book of fish diseases". T.F.H. Publ.; Neatune city, New Jercy p: 117-135.

Attia, Y. (2004): Studies on some diseases affecting the gills of some cultured fishes in Egypt. Ph. D., Fish Diseases and Management Dept., Faculty of Vet. Med., Zag. Univ.

Awad (2007): Studies on some prevailing parasitic diseases among cultured carp fishes. M.V.Sc., Fish Disease Dept., Fac. Vet. Med., Suez Canal Univ.

Ayotunde, E.O; Ochang, S.N. and Okey, I.B. (2007): "Parasitological examinations and food composition in the gut of feral African carp, Labeo coubie in the Cross River, Southeastern, Nigeria". African Journal of Biotechnology, 6, 5: 625-630.

Bowers, D.G; Harker, P.S.D; Smith, P.T. (2000): "Optical Properties of a Region of freshwater influence". Estuarine, Coastal\&Shelf Science, Volume 50, Issue 5, Pages 717-726.

Brewster, B. (1997): "Keeping Koi health." Aquar. Pondkeep., 61 (12): 21-25

Cedric, K. and Neil, W. (2007): (Intervet Norbio Singapore) In the last three issues of the Intervet Aquatic Animal Health Newsletter, we presented a series of articles on tilapia diseases.

Cusack, R. and Cone, D.K. (1986): A review of parasites as vectors of viral and bacterial diseases of fish. J. of Fish Dis. 9: 169-171.

Dewra, H. I. M. (1995): "Some studies on gill affections of some freshwater fishes." M.V. Sc. Thesis, Fac. of Vet. Med., Suez Canal University. 
Eissa, I.A.; Badran, A.F.; Diab, A.S. and Layla, F. (2000): Studies on yellow grup diseases in some freshwater fishes. $1^{\text {st }}$ Scientific Conf. Suez Canal. Med.

El-Gawady, H.M.; Eissa, I.A. and Badran, A.F. (1992): "The prevalent ectoparasitic diseases of Oreochromis niloticus Fish in Ismailia city and their control." Zag. Vet. J. (EGVMC)., 20(2), 277-285.

El-Gohary, M.S.A. (2000): "Studies on monogenetic trematoded in freshwater fish with special Reference to their control." M. V. Sc. Thesis, Fac. of Vet. Med., Alexandria Univ.

El-Nobi, G. (1998): Studies on the main parasitic diseases affecting the skin in some Nile fishes. Ph. D., Fish Siseases and Management Dept., Faculty of Vet. Med., Zag. Univ.

Gihan, A.A. (1999): Marine fish Parasitology of some fresh water fish at Abbassa in Sharkia Governorate M. V. Sc. thesis (Parasitology) Zagazig Univercity.

Grabda, J. (1991): "Marine Fish Parasitology". VCH, New York.

Innes, W.T. (1966): Exotic aquarium fishes. $19^{\text {th }} \mathrm{Ed}$ aquarium incorporated. New Jersey, pp 12-25, 29-30 and 530-533.

Kabata, Z. (1985): Parasites and Diseases of fish cultured in tropics. Tylor and Francis, London \& Philadelphia.

Lau, A.; Chen, S.; Sleiman, S. and Sorrell, T. (2009): Current status and future perspectives on molecular and serological methods in diagnostic mycology. Future Microbiol. Nov; 4: 1185-222. Review.PMID: 19895220.

Lucky, Z. (1977): "Methods for the diagnosis of fish diseases." Amerind Publ. Co. Pv Ltd., New York, $1^{\text {st }}$ Ed.

Mesalhy, S.A. (1994): "Pathological Studies on some fish in Suez Canal area." Ph. D. Thesis, Fac. Vet. Med., Suez Canal University.

Molnar, K. and Szekely, C. (1997): "An unusual location of Ergasilus sieboldi nordmann (Copepoda, Ergasilidae) on the operculum and base of pectoral fin of pick perch (Stizostedion luioperca)". Acta-Veterinaria-Hungarica. 45: 2, 165-175.

Moravec, F. and Scholz, T. (1994): Observation on the development of Syncuaria squamata (Nematoda: Acuariidae), a parasite of cormorants, in the intermediate and paratenic hosts. Folia Parasitol (Praha). 41 (3): 183-92.

Morozinska-Gogol, J. (2002): "Seasonal variation of parasite infection of three-spinal stickleback (Gasterosteus aculeateis L.) in the Southern Baltic." Wiad Parazytol., 48(4): 359-373. 
Mostafa, M.; Ibrahim, M. and Easa, M. El-S. (1991): "The effect of seasonal variation on the development of parasitic gill diseases in Cichilid fish." Banha Vet. Med. J., Vol.2 (3).

Naguib, M. (1994): "Studies on bacterial and mycotic affections of freshwater fishes in aquaculture." Ph. D. Thesis, Faculty of Vet. Med., Cairo, Univ.

Newaj-fyzul, A.; Mutani, A.; Ramsubhag, A.; Adesiyum, A. (2008): "Prevalence of Bacterial Pathogenes and their Anti-microbial Resistance in Tilapia and other pond water in Trinidad". Zoonoses and Public Health 55, 4: 206-213(8).

Noga, E.J. (1996): "Text Book of Fish Diseases, diagnosis and treatment." Walsworth Publishing Co., U.S.A.

Omar, M.A.; Oosterhout, C.Van.; Blais, J.; Robinson, R.L. and Cable, J. (2008): "On the Ecology and Host Relationships of Acanthogyrus (Acanthosentis) tilapiae (Acanthocephala: Quadrigyridae) from Cichlids in Lake Malawi". The Helminthological Society of Washington Comparative Parasitology 75(2): 278-282.

Osama, H.M.; Solman, W.E.; Noor EL Deen, A.E. and Mohamed, L.A. (2008): Induction of Saprolegniosis Oreochromis niloticus with special Reference to its Biological control. Global Veterinary 2(1): 32-37.

Paperna, I. (1996): Parasites, infections and diseases of fishes in Africa - An update CIFA Technical Paper. No.31. Rome, FAO. 220p.

Plumb, J.A. (1999): "Overview of Warmwater Fish Diseases". Journal of Applied Aquaculture, 9, 2: 1-10.

Polacheck, I. (2007): PhD, Department of Clinical Microbiology \& Infectious Diseases, Faculty of Medicine, August 2007. Mother \& Child Pavilion, Hadassah Ein Kerem.

Ramadan, H.H. (1991): "Effect of host species, sex, length, diet and different seasons on the parasitic infested of Tilapia fish in Lake Manzalah." J. King. Abdulaziz Univ. Mar Sci. 2: 81-91.

Ruth, F. (1990): "Fisheries and Aquatic Sciences (SFRC) | Fish Health Management" This document is CIR921, one of a series of the Fisheries and Aquatic Sciences Department, Florida Cooperative Extension Service, Institute of Food and Agricultural Sciences, http://edis.ifas.ufl.edu.

Salah, B.S.; Bandyopadhya, P.K. and Haldar, D.P. (1995): Seasonal incidence in the distribution of urceolariid ciliated protozoa in 
freshwater fishes of west Bengal. Environ. Eco., 13 (4): 837852.

Stueland, S.; Hatati, K. and Skaar, I. (2005): Morphologycal and physiological characteristics of Saprolegnia spp., strains pathogenic to Atlantic salmon, Salmosalar L. Journal of Fish Diseases, 28(8): 445-453.

Tully, O. and Nolan, D.T. (2002): Areview of population biology and host-parasite interactions of the sea louse Lepeophtheirus Salmonis (Copepoda:Caligidae) Parasitology 124: 165-182.

Udomkusonsri, P. (2003): Pathogenesis of the acute ulceration response (AUR) in fish. A Disseration submitted to the graduate faculty of North Carolina State University in partial fulfillment of the requirements for PHD. Comparative Biomedical Sciences.

Varjabedian, K.G. (1993): Studies on parasitic nematodes infecting some locality consumed fish in Egypt. Ph. D. Thesis, Faculty of Science, Cairo, University.

Willough, L.G. (1978): Saprolegniosis of salamonid fish in Windermere: A critical analysis. J. of Fish Diseases, 1, 51-67.

WO (2007): TTO-BASED wide spectruum therapeutics, disinfectants \& anesthetics for use in aquaculture. The World Intellectual Property Organization (WIPO) is a specialized agency of the United Nations.

Woo, P.T. (2006): Fish diseases and disorders. CABI Publish., London, U.K.

Woo, P.T.K. and Bruno, D.W. (1999): Fish diseases and disorders: Vol. 3: Bacterial, Viral and Fungal infections. CABI Co., London, U.K.

Yimer, E. (2000): Preliminary survey of parasites and bacterial pathogens of fish at Lake Ziway.: Ethiopian Journal of Science 23, 1:25-33.

Younis (1999): "Effect of some ectoparasitic on the blood and serum constituents of Oreochromis niloticus fish with referring to treatment" Beni- Suef. J., 9(3-19).

Zaki, M.S.; Olfat, M.F. and El-Jackey, J. (2008): "Pathological and biochemical studies in Tilapia nilotica infected with Saprolegnia parasitica and treated with potassium permanganate. American-Eurasian J. Agric. \& Environ. Sci., 3 (5): 677-680. 